
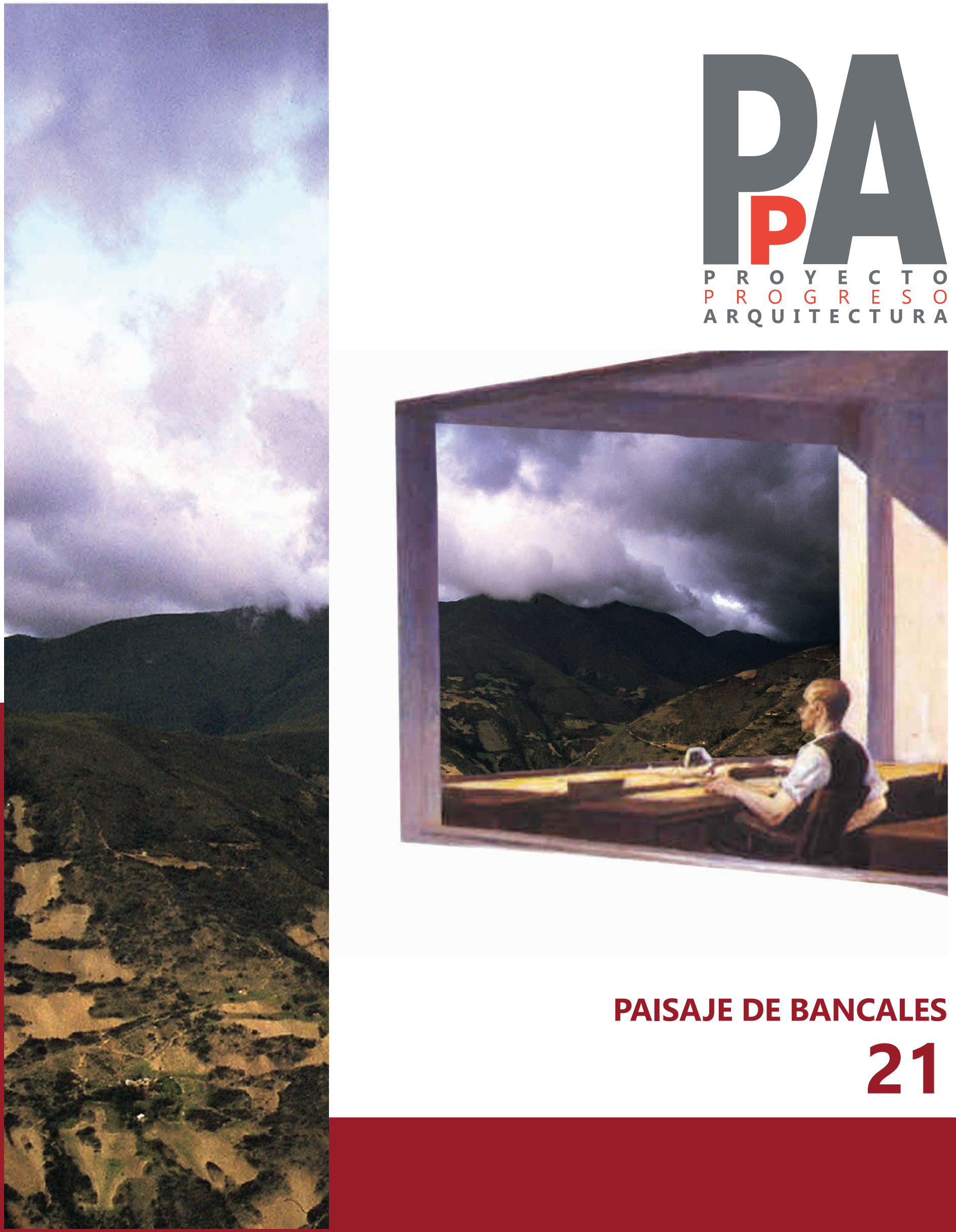

PAISAJE DE BANCALES

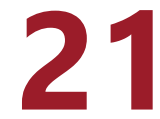




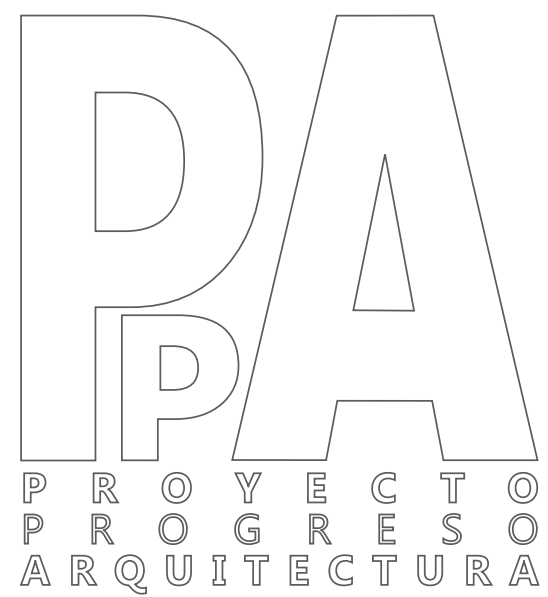

\section{PAISAJE DE BANCALES \\ 21}
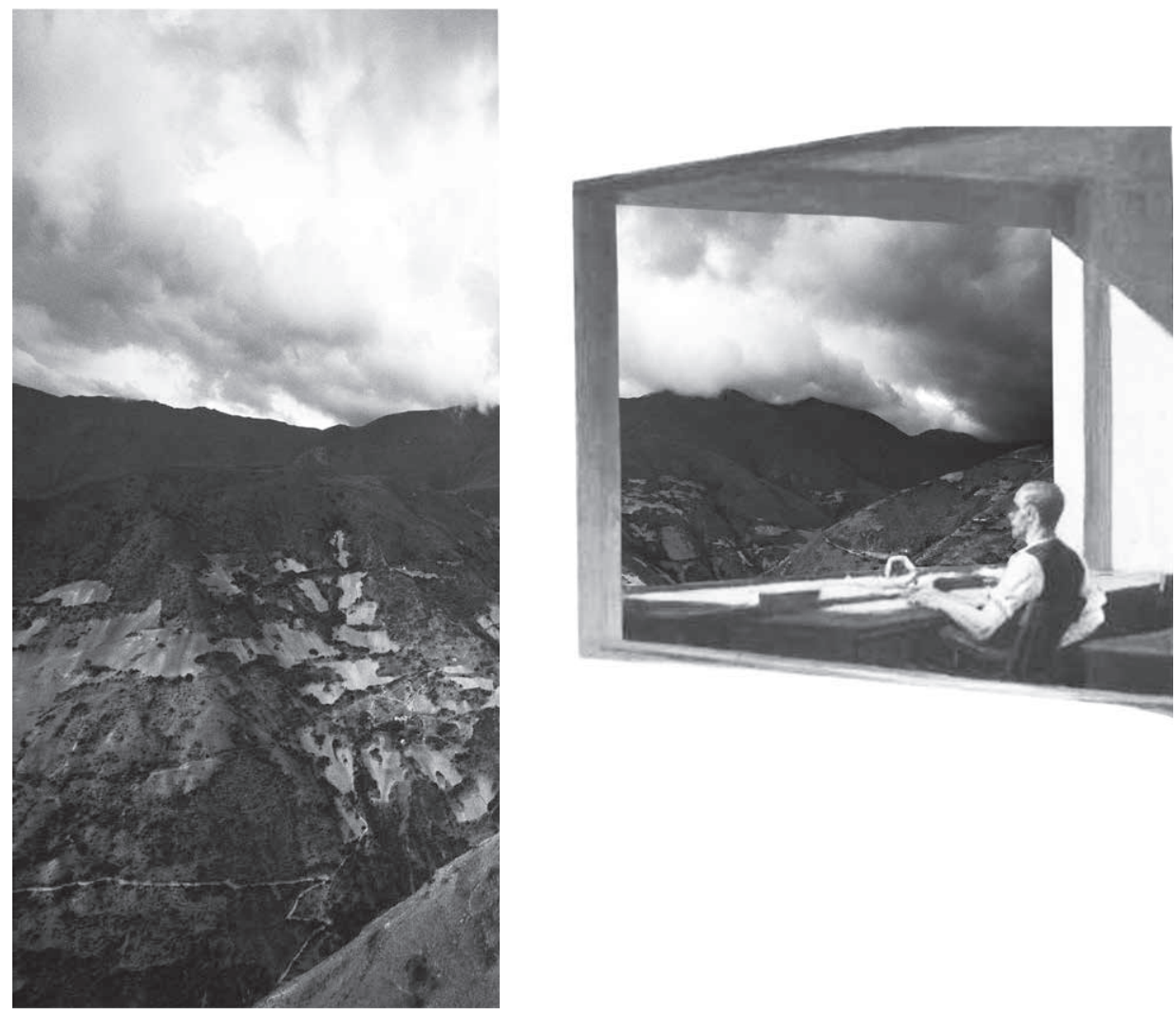


\section{REVISTA PROYECTO PROGRESO ARQUITECTURA}

N22]

\section{paisaje de bancales}
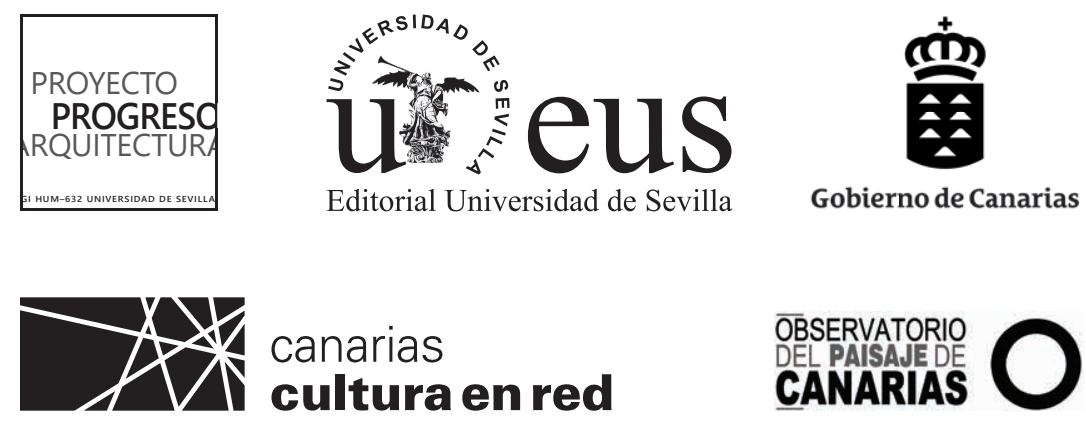
PROYECTO, PROGRESO, ARQUITECTURA. N21, NOVIEMBRE 2019 (AÑO X)

\section{paisaje de bancales}

\section{DIRECCIÓN}

Dr. Amadeo Ramos Carranza. Escuela Técnica Superior de Arquitectura. Universidad de Sevilla. España

\section{SECRETARÍA}

Dra. Rosa María Añón Abajas. Escuela Técnica Superior de Arquitectura. Universidad de Sevilla. España

\section{EQUIPO EDITORIAL}

Edición:

Dr. Amadeo Ramos Carranza. Escuela Técnica Superior de Arquitectura. Universidad de Sevilla. España.

Dra. Rosa María Añón Abajas. Escuela Técnica Superior de Arquitectura. Universidad de Sevilla. España.

Dr. Francisco Javier Montero Fernández. Escuela Técnica Superior de Arquitectura. Universidad de Sevilla. España.

Dr. Alfonso del Pozo Barajas. Escuela Técnica Superior de Arquitectura. Universidad de Sevilla. España.

Dra. Esther Mayoral Campa. Escuela Técnica Superior de Arquitectura. Universidad de Sevilla. España.

Dr. Miguel Ángel de la Cova Morillo-Velarde. Escuela Técnica Superior de Arquitectura. Universidad de Sevilla. España. Dr. Germán López Mena. Escuela Técnica Superior de Arquitectura. Universidad de Sevilla. España.

Juan José López de la Cruz. Escuela Técnica Superior de

Arquitectura. Universidad de Sevilla. España.

Guillermo Pavón Torrejón. Escuela Técnica Superior de Arquitectura. Universidad de Sevilla. España.

Asesores externos a la edición:

Dr. Alberto Altés Arlandis. Post-Doctoral Research Fellow. Architecture Theory Chair . Department of Architecture. TUDelft. Holanda.

Dr. José Altés Bustelo. Escuela Técnica Superior de Arquitectura. Universidad de Valladolid. España.

Dr. José de Coca Leicher. Escuela de Arquitectura y Geodesia. Universidad de Alcalá de Henares. España.

Dr. Jaume J. Ferrer Fores. Escola Tècnica Superior d'Arquitectura de Barcelona. Universitat Politècnica de Catalunya. España.

Dra. Marta Sequeira. CIAUD, Faculdade de Arquitectura da

Universidade de Lisboa, Portugal.

Dr. Carlos Arturo Bell Lemus. Facultad de Arquitectura. Universidad del Atlántico. Colombia.

Carmen Peña de Urquía, architect en RSH-P. Londres. Reino Unido.

SECRETARÍA TÉCNICA

Gloria Rivero Lamela, arquitecto.Personal Investigador en Formación. Universidad de Sevilla. España.

MAQUETA DE LA PORTADA

Miguel Ángel de la Cova Morillo-Velarde

DISEÑO GRÁFICO DE LA MAQUETACIÓN

Maripi Rodríguez

PORTADA:

Del cartel del seminario y de la portada del libro Arquitectura y construcción: el paisaje como argumento(2009). Dir: Ramos-

Carranza, Amadeo; Añón-Abajas, Rosa María

Diseño del cartel: Valentín Trillo Martínez (2007)

ISSN (ed. impresa): 2171-6897

ISSN-e (ed. electrónica): 2173-1616

DOI: http://dx.doi.org/10.12795/ppa

DEPÓSITO LEGAL: SE-2773-2010

PERIOCIDAD DE LA REVISTA: MAYO Y NOVIEMBRE

IMPRIME: PODIPRINT

INICIATIVA DEL GRUPO DE INVESTIGACION HUM-632

"PROYECTO, PROGRESO, ARQUITECTURA"

http://www.proyectoprogresoarquitectura.com
COORDINADOR DE LOS CONTENIDOS CIENTÍFICOS DEL NÚMERO

Dra. Juan Manuel Palerm Salzar. Escuela Técnica Superior de Arquitectura. Universidad de Las Palmas. España.

COMITÉ CIÉNTIFICO

Dr. Gonzalo Díaz Recaséns. Catedrático Proyectos Arquitectónicos. Escuela Técnica Superior de Arquitectura. Universidad de Sevilla. España.

Dr. José Manuel López Peláez. Catedrático Proyectos Arquitectónicos.

Escuela Técnica Superior de Arquitectura. Universidad Politécnica de Madrid. España.

Dr. Víctor Pérez Escolano. Catedrático Historia, Teoría y Composición Arquitectónicas. Escuela Técnica Superior de Arquitectura. Universidad de Sevilla. España.

Dr. Jorge Torres Cueco. Catedrático Proyectos Arquitectónicos. Escuela Técnica Superior de Arquitectura. Universitat Politècnica de València. España. Dr. Armando Dal'Fabbro. Professore Associato. Dipartimento di progettazione architettonica, Facoltà di Architettura, Universitat Instituto Universitario di Architettura di Venezia. Italia.

Dra. Anne-Marie Chatelêt. Professeur Titulaire. Histoire et Cultures Architecturales. École Nationale Supérieure d'Architecture de Stragbourg. Francia.

Dr. ir. Frank van der Hoeven, TU DELFT. Architecture and the Built Environment, Netherlands

EDITA

Editorial Universidad de Sevilla. Sevilla

DIRECCIÓN CORRESPONDENCIA CIENTÍFICA

E.T.S. de Arquitectura. Avda Reina Mercedes, nº 2 41012-Sevilla.

Amadeo Ramos Carranza, Dpto. Proyectos Arquitectónicos.

e-mail: revistappa.direccion@gmail.com

EDICIÓN ON-LINE

Portal informático https://revistascientificas.us.es/index.php/ppa Portalinformático G.I.HUM-632 http://www.proyectoprogresoarquitectura.com Portal informático Editorial Universidad de Sevilla http://www.editorial.us.es/

(C) EDITORIAL UNIVERSIDAD DE SEVILLA, 2019

Calle Porvenir, 27. 41013 SEVILLA. Tfs. 954487447 / 954487451

Fax954487443. [eus4@us.es] [http://www.editorial.us.es]

(c) TEXTOS: SUS AUTORES, 2019.

(c) IMÁGENES: SUS AUTORES Y/O INSTITUCIONES, 2019.

SUSCRIPCIONES, ADQUISICIONES Y CANJE revista PROYECTO, PROGRESO, ARQUITECTURA

Editorial Universidad de Sevilla.

Calle Porvenir, 27. 41013 SEVILLA. Tfs. 954487447 / 954487451

Fax 954487443

Reservados todos los derechos. Ni la totalidad ni parte de esta revista puede reproducirse o transmitirse por ningún procedimiento electrónico o mecánico, incluyendo fotocopia, grabación magnética o cualquier almacenamiento de información y sistema de recuperación, sin permiso escrito de la Editorial Universidad de Sevilla.

Las opiniones y los criterios vertidos por los autores en los artículos firmados son responsabilidad exclusiva de los mismos.

COLABORA DEPARTAMENTO DE PROYECTOS ARQUITECTÓNICOS Escuela Técnica Superior de Arquitectura. Universidad de Sevilla. http://www.departamento.us.es/dpaetsas 


\section{revista PROYECTO, PROGRESO, ARQUITECTURA}

Nuestra revista, fundada en el año 2010, es una iniciativa del Grupo de Investigación de la Universidad de Sevilla HUM-632 "proyecto, progreso, arquitectura" y tiene por objetivo compartir y debatir sobre investigación en arquitectura. Es una publicación científica con periodicidad semestral, en formato papel y digital, que publica trabajos originales que no hayan sido publicados anteriormente en otras revistas. Queda establecido el sistema de arbitraje para la selección de artículos a publicar mediante dos revisores externos -sistema doble ciego- siguiendo los protocolos habituales para publicaciones científicas seriadas. Los títulos, resúmenes ,palabras clave y texto completo de los artículos se publican también en lengua inglesa.

"proyecto, progreso, arquitectura" presenta una estructura clara, sencilla y flexible. Trata todos los temas relacionados con la teoría y la práctica del proyecto arquitectónico. Las distintas "temáticas abiertas" que componen nuestra línea editorial, son las fuentes para la conjunción de investigaciones diversas.

La revista va dirigida a arquitectos, estudiantes, investigadores y profesionales relacionados con el proyecto y la realización de la obra de arquitectura.

Our journal, "proyecto, progreso, arquitectura", founded in 2010, is an initiative of the Research Group HUM-632 of the University of Seville and its objective is the sharing and debating of research within architecture. This six-monthly scientific publication, in paper and digital format, publishes original works that have not been previously published in other journals. The article selection process consists of a double blind system involving two external reviewers, following the usual protocols for serial scientific publications. The titles, summaries, key words and full text of articles are also published in English.

"proyecto, progreso, arquitectura" presents a clear, easy and flexible structure. It deals with all the subjects relating to the theory and the practise of the architectural project. The different "open themes" that compose our editorial line are sources for the conjunction of diverse investigations.

The journal is directed toward architects, students, researchers and professionals related to the planning and the accomplishment of the architectural work.

\section{SISTEMA DE ARBITRAJE}

EVALUACIÓN EXTERNA POR PARES Y ANÓNIMA

El Consejo Editorial de la revista, una vez comprobado que el artículo cumple con las normas relativas a estilo y contenido indicadas en las directrices para los autores, remitirá el artículo a dos expertos revisores anónimos dentro del campo específico de investigación y crítica de arquitectura, según el modelo doble ciego.

Basándose en las recomendaciones de los revisores, el director de la revista comunicará a los autores el resultado motivado de la evaluación por correo electrónico, en la dirección que éstos hayan utilizado para enviar el artículo. El director comunicará al autor principal el resultado de la revisión (publicación sin cambios; publicación con correcciones menores; publicación con correcciones importantes; no aconsejable para su publicación), así como las observaciones y comentarios de los revisores.

Si el manuscrito ha sido aceptado con modificaciones, los autores deberán reenviar una nueva versión del artículo, atendiendo a las demandas y sugerencias de los evaluadores externos. Si lo desean, los autores pueden aportar también una carta al Consejo Editorial en la que indicarán el contenido de las modificaciones del artículo. Los artículos con correcciones importantes podrán ser remitidos al Consejo Asesor y/o Científico para verificar la validez de las modificaciones efectuadas por el autor

EXTERNAL ANONYMOUS PEER REVIEW.

When the Editorial Board of the magazine has verified that the article fulfils the standards relating to style and content indicated in the instructions for authors, the article will be sent to two anonymous experts, within the specific field of architectural investigation and critique, for a double blind review.

The Director of the magazine will communicate the result of the reviewers' evaluations, and their recommendations, to the authors by electronic mail, to the address used to send the article. The Director will communicate the result of the review (publication without changes; publication with minor corrections; publication with significant corrections; its publication is not advisable), as well as the observations and comments of the reviewers, to the main author.

If the manuscript has been accepted with modifications, the authors will have to resubmit a new version of the article, addressing the requirements and suggestions of the external reviewers. If they wish, the authors can also send a letter to the Editorial Board, in which they will indicate the content of the modifications of the article. The articles with significant corrections can be sent to Advisory and/or Scientific Board for verification of the validity of the modifications made by the author.

\section{INSTRUCCIONES A AUTORES PARA LA REMISIÓN DE ARTÍCULOS}

NORMAS DE PUBLICACIÓN

Instrucciones a autores: extensión máxima del artículo, condiciones de diseño -márgenes, encabezados, tipo de letra, cuerpo del texto y de las citas-, composición primera página, forma y dimensión del título y del autor/a, condiciones de la reseña biográfica, del resumen, de las palabras claves, de las citas, de las imágenes -numeración en texto, en pié de imágenes, calidad de la imagen y autoría o procedencia- y de la bibliografía en http://www.proyectoprogresoarquitectura.com (> PARTICIPA > POLITICA DE SECCIONES Y NORMAS DE REDACCIÓN / NORMAS BIBLIOGRAFÍA Y CITAS)

PUBLICATION STANDARDS

Instructions to authors: maximum length of the article, design conditions (margins, headings, font, body of the text and quotations), composition of the front page, form and size of the title and the name of the author, conditions of the biographical review, the summary key words, quotations, images (text numeration, image captions, image quality and authorship or origin) and of the bibliography in http://www.proyectoprogresoarquitectura.com (> PARTICIPA > POLÍTICA DE SECCIONES Y NORMAS DE REDACCIÓN / NORMAS BIBLIOGRAFÍA Y CITAS) 


\section{SERVICIOS DE INFORMACIÓN}

\section{CALIDAD EDITORIAL}

La Editorial Universidad de Sevilla cumple los criterios establecidos por la Comisión Nacional Evaluadora de la Actividad Investigadora para que lo publicado por el mismo sea reconocido como "de impacto" (Ministerio de Ciencia e Innovación, Resolución 18939 de 11 de noviembre de 2008 de la Presidencia de la CNEAI, Apéndice I, BOE nº 282, de 22.11.08).

La Editorial Universidad de Sevilla forma parte de la U.N.E. (Unión de Editoriales Universitarias Españolas) ajustándose al sistema de control de calidad que garantiza el prestigio e internacionalidad de sus publicaciones.

\section{PUBLICATION QUALITY}

The Editorial Universidad de Sevilla fulfils the criteria established by the National Commission for the Evaluation of Research Activity (CNEAl) so that its publications are recognised as "of impact" (Ministry of Science and Innovation, Resolution 18939 of 11 November 2008 on the Presidency of the CNEAl, Appendix I, BOE No 282, of 22.11.08).

The Editorial Universidad de Sevilla operates a quality control system which ensures the prestige and international nature of its publications, and is a member of the U.N.E. (Unión de Editoriales Universitarias Españolas-Union of Spanish University Publishers).

Los contenidos de la revista PROYECTO, PROGRESO, ARQUITECTURA aparecen en:

\section{bases de datos: indexación}

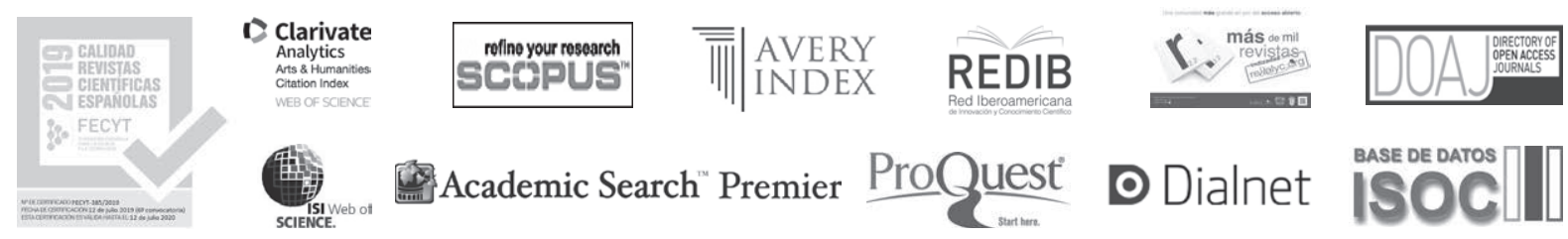

\section{SELLO DE CALIDAD EDITORIAL FECYT 2019}

WoS. Arts \& Humanities Citation Index WoS. ESCl - Emerging Sources Citation Index SCOPUS

AVERY. Avery Index to Architectural Periodicals

REBID. Red Iberoamericana de Innovación y Conocimiento Científico

REDALYC. Red de Revistas Científicas de América Latina y el Caribe, España y Portugal.

EBSCO. Fuente Académica Premier

EBSCO. Art Source

DOAJ, Directory of Open Access Journals

PROQUEST (Arts \& Humanities, full text)

DIALNET

ISOC (Producida por el CCHS del CSIC)

DRIJ. Directory of Research Journals Indexing

SJR (2018): 0.111, H index: 2 CUARTIL: Q3

\section{catalogaciones: criterios de calidad}

RESH (Revistas Españolas de Ciencias Sociales y Humanidades).

Catálogos CNEAI (16 criterios de 19). ANECA (18 criterios de 21). LATINDEX (35 criterios sobre 36).

DICE (CCHS del CSIC, ANECA)

MIAR, Matriu d'Informació per a l'Avaluació de Revistes. IDCS 2018: 10,500. Campo ARQUITECTURA

CLASIFICACIÓN INTEGRADA DE REVISTAS CIENTÍFICAS (CIRC-CSIC): A

ERIHPLUS

SCIRUS, for Scientific Information.

ULRICH'S WEB, Global Serials Directory.

ACTUALIDAD IBEROAMERICANA.

catálogos on-line bibliotecas notables de arquitectura:

CLIO. Catálogo on-line. Columbia University. New York

HOLLIS. Catálogo on-line. Harvard University. Cambridge. MA

SBD. Sistema Bibliotecario e Documentale. Instituto Universitario di Architettura di Venezia

OPAC. Servizi Bibliotecari di Ateneo. Biblioteca Centrale. Politecnico di Milano

COPAC. Catálogo colectivo (Reino Unido)

SUDOC. Catálogo colectivo (Francia)

ZBD. Catálogo colectivo (Alemania)

REBIUN. Catálogo colectivo (España)

OCLC. WorldCat (Mundial) 


\section{DECLARACIÓN ÉTICA SOBRE PUBLICACIÓN Y MALAS PRÁCTICAS}

La revista PROYECTO, PROGRESO, ARQUITECTURA (PPA) está comprometida con la comunidad académica en garantizar la ética y calidad de los artículos publicados. Nuestra revista tiene como referencia el Código de Conducta y Buenas Prácticas que, para editores de revistas científicas, define el COMITÉ DE ÉTICA DE PUBLICACIONES (COPE).

Así nuestra revista garantiza la adecuada respuesta a las necesidades de los lectores y autores, asegurando la calidad de lo publicado, protegiendo y respetando el contenido de los artículos y la integridad de los mismo. El Consejo Editorial se compromete a publicar las correcciones, aclaraciones, retracciones y disculpas cuando sea preciso.

En cumplimiento de estas buenas prácticas, la revista PPA tiene publicado el sistema de arbitraje que sigue para la selección de artículos así como los criterios de evaluación que deben aplicar los evaluadores externos -anónimos y por pares, ajenos al Consejo Editorial-. La revista PPA mantiene actualizados estos criterios, basados exclusivamente en la relevancia científica del artículo, originalidad, claridad y pertinencia del trabajo presentado.

Nuestra revista garantiza en todo momento la condifencialidad del proceso de evaluación: el anonimato de los evaluadores y de los autores; el contenido evaluado; los informes razonados emitidos por los evaluadores y cualquier otra comunicación emitida por los consejos Editorial, Asesor y Científico si así procediese.

Igualmente quedan afectados de la máxima confidencialidad las posibles aclaraciones, reclamaciones o quejas que un autor desee remitir a los comités de la revista o a los evaluadores del artículo.

La revista PROYECTO, PROGRESO, ARQUITECTURA (PPA) declara su compromiso por el respeto e integridad de los trabajos ya publicados. Por esta razón, el plagio está estrictamente prohibido y los textos que se identifiquen como plagio o su contenido sea fraudulento, serán eliminados o no publicados por la revista PPA. La revista actuará en estos casos con la mayor celeridad posible. Al aceptar los términos y acuerdos expresados por nuestra revista, los autores han de garantizar que el artículo y los materiales asociados a él son originales o no infringen derechos de autor. También los autores tienen que justificar que, en caso de una autoría compartida, hubo un consenso pleno de todos los autores afectados y que no ha sido presentado ni publicado con anterioridad en otro medio de difusión.

\section{ETHICS STATEMENT ON PUBLICATION AND BAD PRACTICES}

PROYECTO, PROGRESO ARQUITECTURA (PPA) makes a commitment to the academic community by ensuring the ethics and quality of its published articles. As a benchmark, our journal uses the Code of Conduct and Good Practices which, for scientific journals, is defined for editors by the PUBLICATION ETHICS COMMITTEE (COPE).

Our journal thereby guarantees an appropriate response to the needs of readers and authors, ensuring the quality of the published work, protecting and respecting the content and integrity of the articles. The Editorial Board will publish corrections, clarifications, retractions and apologies when necessary.

In compliance with these best practices, PPA has published the arbitration system that is followed for the selection of articles as well as the evaluation criteria to be applied by the anonymous, external peer-reviewers. PPA keeps these criteria current, based solely on the scientific importance, the originality, clarity and relevance of the presented article.

Our journal guarantees the confidentiality of the evaluation process at all times: the anonymity of the reviewers and authors; the reviewed content; the reasoned report issued by the reviewers and any other communication issued by the editorial, advisory and scientific boards as required.

Equally, the strictest confidentiality applies to possible clarifications, claims or complaints that an author may wish to refer to the journal's committees or the article reviewers.

PROYECTO, PROGRESO ARQUITECTURA (PPA) declares its commitment to the respect and integrity of work already published. For this reason, plagiarism is strictly prohibited and texts that are identified as being plagiarized, or having fraudulent content, will be eliminated or not published in PPA. The journal will act as quickly as possible in such cases. In accepting the terms and conditions expressed by our journal, authors must guarantee that the article and the materials associated with it are original and do not infringe copyright. The authors will also have to warrant that, in the case of joint authorship, there has been full consensus of all authors concerned and that the article has not been submitted to, or previously published in, any other media. 
PROYECTO, PROGRESO, ARQUITECTURA. N21, NOVIEMBRE 2019 (AÑO X)

\section{paisaje de bancales}

índice

editorial

ARQUITECTURA DE LA MONÓTONA REPETICIÓN. PAISAJE DE BANCALES / ARCHITECTURE OF THE MONOTTON REPETITION. TERRACES LANDSCAPES

Juan Manuel Palerm Salazar - (DOI: http://dx.doi.org/10.12795/ppa.2019.121.12

entre líneas

ATAPTED SLOPES

Lucija Ažman Momirskis - (DOl: http://dx.doi.org/10.12795/ppa.2019.i21.01)

artículos

BANCALES HABITADOS: DE LA REUTILIZACIÓN EN LA ARQUITECTURA TRADICIONAL AL TRABAJO CON EL TIEMPO DE CÉSAR MANRIQUE Y SOUTO DE MOURA / FLIVING TERRACES: FROM REUSE IN TRADITIONAL ARCHITECTURE TO CÉSAR MANRIQUE AND SOUTO DE MOURA'S WORK WITH TIME

Francisco Javier Castellano Pulido - (DOI: http://dx.doi.org/10.12795/ppa.2019.121.02)

ESTRATEGIAS TERRITORIALES INTEGRALES PARA LA PUESTA EN VALOR DE PAISAJE CULTURAL AGRÍCOLA. LA RIBEIRA SACRA, GALICIA, ESPAÑA / COMPREHENSIVE TERRITORIAL STRATEGIES TO ENHANCE THE AGRICULTURAL-CULTURAL LANDSCAPE. RIBEIRA SACRA, GALICIA, SPAIN

Susana López Varela - (D0I: http://dx.doi.org/10.12795/ppa.2019.i21.03)

PAISAJES DE ALTURA: LOS ANDENES DEL DISTRITO DE CABANA, VALLE DEL SONDONDO, PERÚ / HIGH LANDSCAPES: THE ANDENES OF THE DISTRIT OF CABANA, SONDONDO VALLEY, PERU Sonia Delgado Berrocal - (DOl: http://dx.doi.org/10.12795/ppa.2019.i21.04)

COLTIVARE I TERRAZZAMENTI AI PIEDI DEL MONTE BIANCO. LA "VITICOLTURA EROICA" DI MORGEX / CULTIVATING THE TERRACES AT THE FOOT OF MONT BLANC. THE "HEROIC VITICULTURE" OF MORGEX

Beatrice Agulli - (DOl: http://dx.doi.org/10.12795/ppa.2019.121.05)

SIAH DAREH. TERRAZAS Y PAISAJE EN ABBAS KIAROSTAMI / SIAH DAREH. TERRACES AND LANDSCAPE IN ABBAS KIAROSTAMI

Pablo López Santana - (DOl: http://dx.doi.org/10.12795/ppa.2019.121.06)

FRANK LLOYD WRIGHT. TRABAJAR LA TIERRA PARA UN PAISAJE SIMBIÓTICO / FRANK LLOYD WRIGHT. EARTHWORK FOR A SYMBIOTIC LANDSCAPE

José María Jové Sandoval - (D0l: http://dx.doi.org/10.12795/ppa.2019.i21.07)

ROGELIO SALMONA Y LA CONSTRUCCIÓN DEL LÍMITE. DIÁLOGOS ENTRE TOPOGRAFÍA Y PAISAJE / ROGELIO SALMONA AND THE CONSTRUCTION OF LIMITS. DIALOGUES BETWEEN TOPOGRAPHY AND LANDSCAPE

Clara Mejía Vallejo; Ricardo Merí de la Maza - (D0l: http://dx.doi.org/10.12795/ppa.2019.i21.08)

reseña bibliográfica TEXTOS VIVOS

RODRIGO ALMONACID CANSECO: EL PAISAJE CODIFICADO EN LA ARQUITECTURA DE ARNE JACOBSEN

Carlos Santamarina-Macho - (DOI: http://dx.doi.org/10.12795/ppa.2019.i21.09)

JAVIER MADERUELO: EL PAISAJE. GÉNESIS DE UN CONCEPTO

Victoriano Sainz Gutiérrez - (DOI: http://dx.doi.org/10.12795/ppa.2019.121.10)

GEORG SIMMEL: FILOSOFÍA DEL PAISAJE

Esther Mayoral Campa - (DOI: http://dx.doi.org/10.12795/ppa.2019.i21.11)

VERSIÓN EN INGLÉS A TEXTO COMPLETO DE TODOS LOS ARTICULOS, EN LA EDICIÓN ON-LINE https://revistascientificas.us.es/index.php/ppa y http://www.proyectoprogresoarquitectura.com/ 

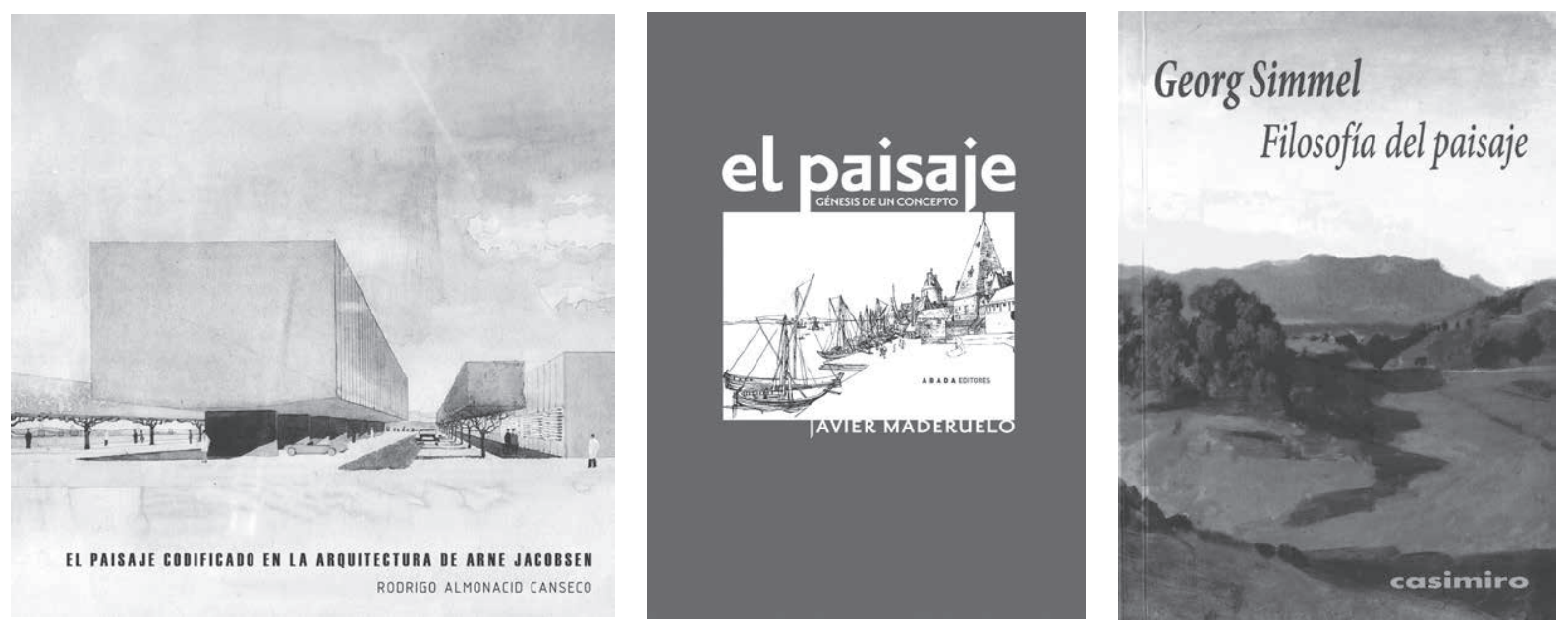

\section{reseña bibliográfica TEXTOS VIVOS}

Nuestra época está sometida a transformaciones hasta ahora insospechadas a cuya aparición no somos ajenos y que afectan a la forma de entender y practicar la arquitectura.

El entendimiento y la acción en la nueva arquitectura no deben abordarse solo desde la racionalidad del proyecto sino desde la reconstrucción crítica de la memoria de nuestra cultura y de nuestra participación en ella a lo largo del tiempo y en la evolución de la sociedad.

Cada tiempo, y el nuestro también, decide qué arquitectos y cuáles textos y obras han de ser rescatados y recalificados como clásicos.

Mediante el diálogo con ellos, los arquitectos actuales nos alinearemos en la tradición arquitectónica de la que, hoy, de manera perentoria, no es posible ni razonable prescindir. PROYECTO, PROGRESO, ARQUITECTURA destina esta sección a realizar un repaso propositivo y abierto a esos textos. 


\title{
GEORG SIMMEL: FILOSOFÍA DEL PAISAJE
}

\author{
Madrid: Casimiro, 2013. 64 páginas, formato 12 × 17 cm. ISBN: 978-84-15715-12-2
}

Esther Mayoral Campa (https://orcid.org/0000-0003-2085-7020)

Dra. arquitecto, profesora contratada doctora del Departamento de Proyectos Arquitectónicos. Escuela Técnica Superior de Arquitectura, Universidad de Sevilla, España

Persona de contacto: esthermc@us.es

o pocas veces puede ocurrir que, paseando por la naturaleza, nos fijemos, con mayor o menor
atención, en cuanto nos rodea: Ios árboles y los cursos de agua, las colinas y las construcciones,
la luz y las nubes en sus infinitas transformaciones. Detenerse en un detalle o advertir varios a la vez no basta, sin embargo, para tener conciencia de estar ante un 'paisaje'".

Con estas palabras comienza Georg Simmel (Berlín, 1858-Estrasburgo, 1918) su libro Filosofía del paisaje, un pequeño texto de una enorme fuerza narrativa e influencia en la conceptualización y definición del término paisaje. Un libro y un autor que han ido ganando relevancia desde las últimas décadas del siglo XX hasta nuestros días, a medida que el concepto de "paisaje" se ha consolidado, como una de las ideas centrales del pensamiento filosófico sociológico, artístico y arquitectónico contemporáneo.

Los escritos de Simmel, por su audacia y originalidad, muestran la fuerza de las ideas pioneras. Se enmarca en aquellos pensadores que en su contexto cultural tuvieron un papel periférico, pero que, desde esa posición ideológica descentralizada, consiguieron entender y construir herramientas para comprender el complejo mundo contemporáneo.

Simmel, filósofo, sociólogo y profesor muy valorado, pero solo reconocido académicamente al final de su vida, fue un autor profundamente comprometido con su época. Mantuvo amistad con pensadores y artistas como Max Weber o Reiner Maria Rilke, además de colaborar con filósofos tan importantes como Edmund Husserl o Walter Benjamin.

A pesar de ello, y de su enorme influencia en la filosofía y, sobre todo, en la sociología desde los años 50 del siglo XX — se le considera padre del estructuralismo y su pensamiento fue fundamental para la Escuela de Fráncfort-, sus planteamientos teóricos no siempre fueron bien acogidos por sus coetáneos. En cierto sentido, Georg Simmel fue un adelantado a su época, con un pensamiento creativo que busca establecer puentes entre la razón y lo sensitivo. Sus teorías sobre la percepción y la forma y su influencia en los comportamientos sociales, así como su enfoque dialéctico y multidisciplinar, serán muy influyentes desde los movimientos de vanguardia de posguerra hasta nuestros días.

Javier Maderuelo, en su libro El paisaje, génesis de un concepto, habla de la cosificación que en la actualidad se hace del término "paisaje". Debido, en parte, a que su definición es muy amplia, ya que pertenece o es utilizada en múltiples campos disciplinares, también existe un extendido uso coloquial del término que amplía su significado hasta englobar todo lo que tiene que ver con el contexto, en una confusión constante con términos como "naturaleza" o "territorio".

Maderuelo habla también de que el término "paisaje" está vinculado a una serie de tópicos procedentes del romanticismo, en los que se vincula la idea de belleza a la idea de naturaleza. Defiende que para entender el concepto de paisaje hay que aproximarse a él, en primer lugar, distanciándose de la identificación entre naturaleza y paisaje y que, en segundo lugar, no hay que entender el paisaje como conjunto de objetos configurados por la naturaleza, o por el ser humano, o como el medio físico donde se desarrolla la vida humana. Según Maderuelo, el paisaje es un constructo, una elaboración mental que los hombres realizan a través de los fenómenos de la cultura. Por tanto, es necesario hacer un esfuerzo de empatía, para comprender cómo cada cultura ha construido su idea de paisaje. En ese sentido, esta es la oportunidad que nos ofrece el libro Filosofía del paisaje, sumergirnos en los orígenes modernos del término "paisaje" desde la cultura centroeuropea de principios del siglo XX.

El libro Filosofía del paisaje es, en realidad, la recopilación de cuatro artículos sobre este tema, que se reúnen siguiendo un criterio conceptual, y no temporal: "Filosofía del paisaje" (1913), "Los paisajes de Böcklin" (1907), "Las ruinas" (1907) y "Los Alpes" (1911). 
El primero de ellos, "Filosofía del paisaje", es el que tiene un contenido de mayor calado, ya que nos acerca a la definición que hace Georg Simmel de paisaje. Podemos ver cómo las ideas de Maderuelo hunden sus raíces en las de Simmel. Para Simmel, igual que para Maderuelo, el paisaje tiene que ver con un fragmento discreto de realidad, acotado, cualificado y transformado como paisaje — construcción cultural- por un individuo o conjunto de individuos. El ensayo de Simmel define cada uno de estos aspectos del término.

Lo primero que se aborda es una caracterización de la base sobre la que se construye el paisaje. Para Simmel, esta podía ser natural o construida por el hombre, pero excluye la vida urbana como posible base del paisaje. Esto se debe a que, para el autor, ese medio sobre el que se construye el paisaje debe ser un espacio continuo, infinito, "unidad fluida del devenir que se expresa en la continuidad de la existencias espacial y temporal", y los fenómenos urbanos todavía no habían perdido su carácter de objeto finito.

La segunda cuestión es que, para la definición de paisaje, el concepto de "fragmento" es esencial, por lo que el autor nos advierte que dentro del concepto la base será esa naturaleza continua, ese espacio fluido, pero que representadas como paisaje esa base se propone como singularidad óptica, estética o sentimental.

El tercer aspecto también coincide con la definición de Maderuelo de paisaje, al introducir la idea de constructo; el concepto de paisaje incluye la acción de un observador: mirar, interpretar, sentir. Ver como paisaje significa darle unidad a lo que es un fragmento de realidad. Es una dialéctica entre la parte y el todo, una acción de la mente y el alma, una acción que tiene que ver con el acto creativo. Y en este punto es interesante la descripción que hace Simmel del proceso que sigue el artista para construir paisaje: "... entresacar de la corriente caótica e infinita de lo inmediatamente dado una parte, concibiéndola y configurándola como un todo autocontenido y autónomo y cercenando los hilos que la vinculan con el universo para volver a tejerlas autorreferencialmente". ¿Y no está definiendo aquí Simmel el proceso de proyectos?

Si este primer artículo desarrolla la definición de paisaje en todos sus registros, el siguiente artículo, "Los paisajes de Böcklin", enlaza con esta última idea del paisaje como constructo. Aquí Simmel utiliza un caso concreto, los cuadros del pintor alemán Arnold Böcklin (1821-1901), para ilustrar el particular universo creativo del pintor. En este caso, poniendo el foco en la naturaleza ideal y abstracta sobre la que el pintor construye sus paisajes. Fragmentos de una realidad aparte, que mezclan una sensación de pertenencia y emancipación respecto a la naturaleza. Espacios atemporales, encerrados en su propia dimensión, mundo autorreferencial y cerrado en sí mismo que define un universo propio donde los cuadros dictan sus propias leyes, paisajes irreales que Simmel describe con un acentuado lirismo de esta forma: "Así viven [los paisajes del pintor], como la imagen de un ser querido que nos abandonó hace mucho tiempo: una imagen que ha perdido todo rastro de realidad y se confunde totalmente con el sentimiento que nos colma".

En los siguientes dos escritos "Las ruinas" y "Los Alpes", Simmel aborda dos situaciones antagónicas de la naturaleza del paisaje: la naturaleza híbrida y dinámica de las ruinas y la pureza formal y el carácter estático de las montañas de los Alpes. En el primer caso, las ruinas se entienden, frente a otros fragmentos de otras artes, con un carácter más objetual, como parte indisociable de ese continuum natural soporte o base de la idea de paisaje definida por Simmel. Para él es como si, de alguna forma, al desaparecer la coherencia estructural y material que la arquitectura impone a la naturaleza desafiando sus leyes, la naturaleza recuperara parte de su poder sobre lo construido, consiguiendo completar una especie de ciclo holístico donde todo acaba volviendo al lugar del que partió. Frente a esta base artificial, transformada por el poder natural —las ruinas_-, se analiza la naturaleza en estado puro: las montañas de los Alpes. En este caso, se 
reflexiona sobre cómo la forma y la escala pueden modificar la percepción y formar una unidad inseparable de la impresión estética. Además, sobre la dificultad para el artista de aprehensión y construcción de un paisaje de esta naturaleza. La dialéctica entre la vida y la muerte, entre lo bajo y lo alto, entre lo terreno y lo divino, entre lo grande y lo pequeño, se abre paso en "Los Alpes": "La alta montaña produce una impresión de la que derivan tanto la intuición como el símbolo de que la vida puede elevarse hasta liberarse de la forma, hasta trascender y contraponer la forma".

Simmel construye un universo sobre la idea de paisaje lo suficientemente abstracto como para tener continuidad en el presente, ideas germinales que, sin embargo, contienen el potencial evolutivo para seguir teniendo vigencia. Constructos mentales, naturaleza del soporte, dialéctica entre el fragmento y el todo, la autonomía del proceso creativo, la relación entre lo dinámico y lo estático, la integración de opuestos entre lo construido por el hombre y las fuerzas de la naturaleza, la relación entre percepción y forma son temas que aborda este pequeño libro, cargado de intensidad, lirismo e instrumentos para hacernos comprender el paisaje. 

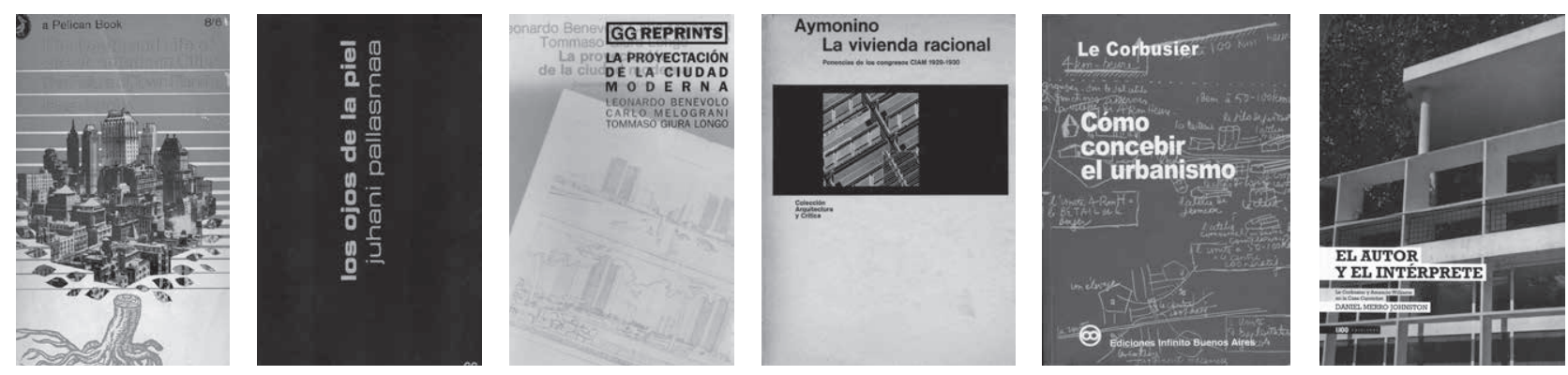

PPA N04: Jane Jacobs: MUERTE Y VIDA DE LAS GRANDES CIUDADES - Juhani Pallasmaa: LOS OJOS DE LA PIEL. LA ARQUITECTURA DE LOS SENTIDOS - Leonardo Benevolo et alt: LA PROYECTACIÓN DE LA CIUDAD MODERNA / PPA N05: Carlo Aymonino: LA VIVIENDA RACIONAL. PONENCIAS DE LOS CONGRESOS CIAM - Le Corbusier: CÓMO CONCEBIR EL URBANISMO - Daniel Merro Johnston: EL AUTOR Y EL INTÉRPRETE. LE CORBUSIER Y AMANCIO WILLIMAS EN LA CASA CURUTCHET
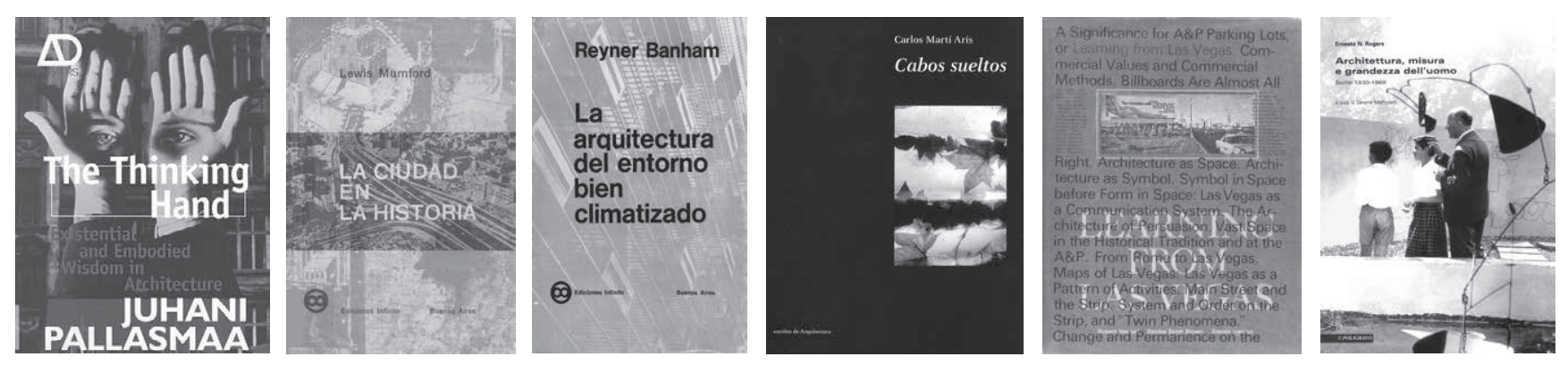

PPA N06: Juhani Pallasmaa: THE THINKING HAND: EXISTENTIAL AND EMBOIDIED WISDOM IN ARCHITECTURE - Lewis Mumford: LA CIUDAD EN LA HISTORIA. SUS ORÍGENES, TRANSFORMACIONES Y PERSPECTIVAS - Reyner Banham: LA ARQUITECTURA DEL ENTORNO BIEN CLIMATIZADO / PPA N07: Carlos Martí Arís: CABOS SUELTOS / PPA N08: Robert Venturi, Denise Scott Brown y Steven Izenour: LEARNING FROM LAS VEGAS / Serena Mafioletti: ARCHITTETURA, MISURA E GRANDEZA DELL'UOMO. SCRITTI 1930-1969
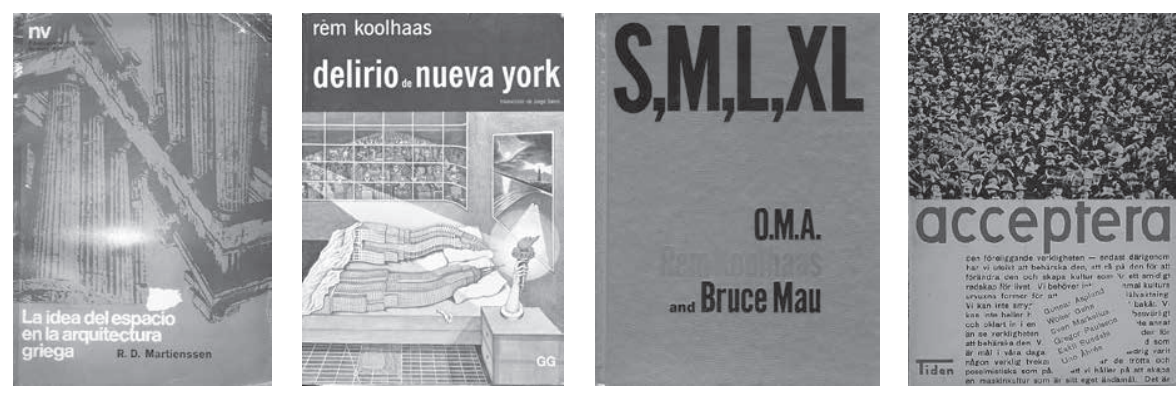

PPA N09: R. D. Martienssen: LA IDEA DEL ESPACIO EN LA ARQUITECTURA GRIEGA / PPA N10: Rem Koolhaas: SMALL, MEDIUM, LARGE, EXTRA-LARGE - Rem Koolhaas: DELIRIO DE NUEVA YORK. UN MANIFIESTO RETROACTIVO PARA MANHATTAN / PPA N11: G. Asplund, W. Gahn, S. Markelius, G. Paulsson, E. Sundahl, U. Åhrén: ACCEPTERA 

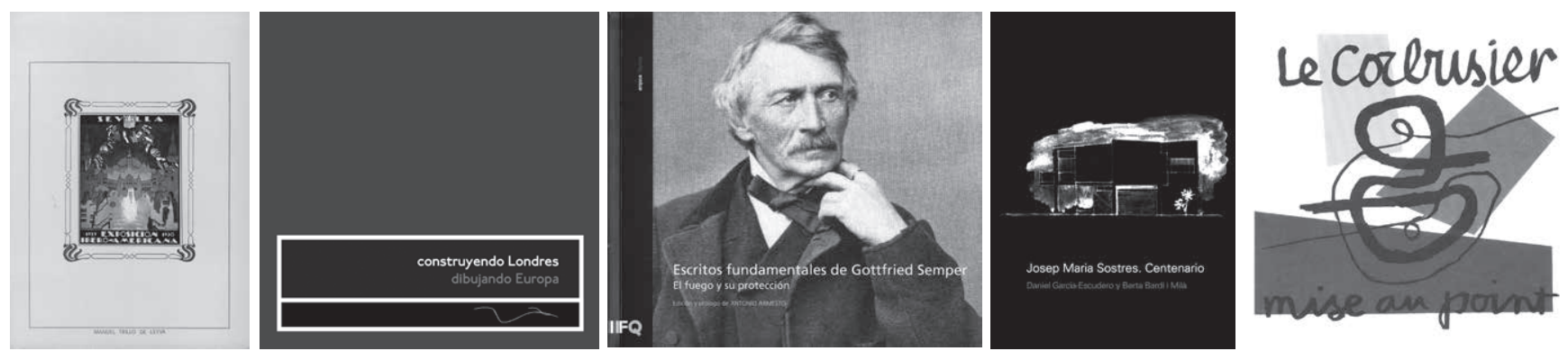

PPA N12: Manuel Trillo de Leyva: LA EXPOSICIÓN IBEROAMERICANA: LA TRANSFORMACIÓN URBANA DE SEVILLA - Manuel Trillo de Leyva: CONSTRUYENDO LONDRES; DIBUJANDO EUROPA / PPA N13: Antonio Armesto (Ed. y Prol.): ESCRITOS FUNDAMENTALES DE GOTTFRIED SEMPER. EL FUEGO Y SU PROTECCIÓN - Daniel García-Escudero y Berta Bardí i milà (Comps.): JOSÉ MARÍA SOSTRES. CENTENARIO - Jorge Torres Cueco (Trad.): LE CORBUSIER. MISE AU POINT
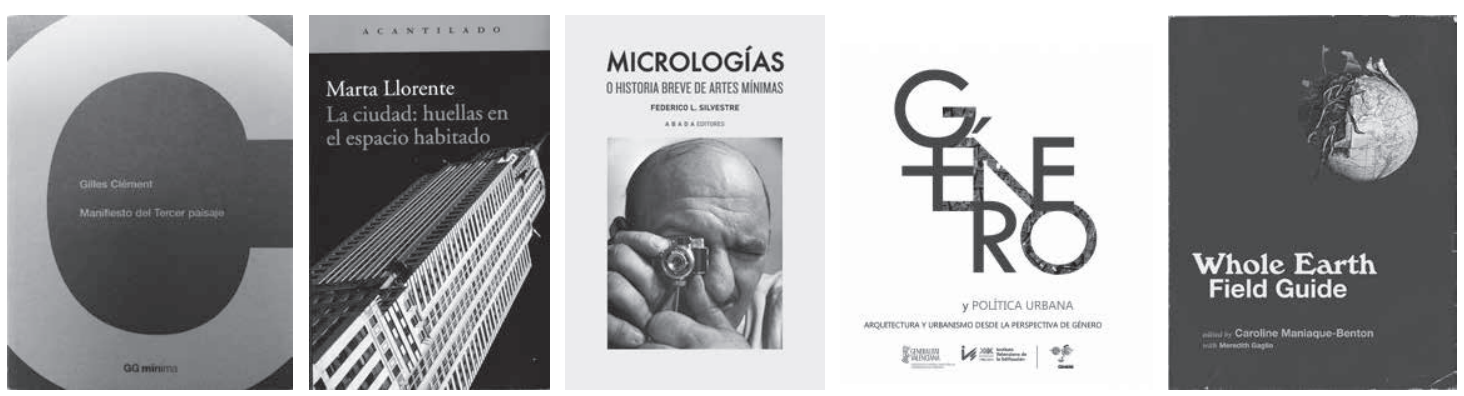

PPA N14: Gilles Clément: MANIFIESTO DEL TERCER PAISAJEERA - Marta Llorente Díaz: LA CIUDAD: HUELLAS EN EL ESPACIO HABITADO / PPA N15: Federico López Silvestre: MICROLOGÍAS O BREVE HISTORIA DE ARTES MÍNIMAS / PPA N16: Begoña Serrano Lanzarote; Carolina Mateo Cecilia; Alberto Rubio Garrido (ED.): GÉNERO Y POLÍTICA URBANA. ARQUITECTURA Y URBANISMODESDE LA PERSPECTIVA DE GÉNERO - Caroline Maniaque-Benton with Merodith Gaglio (EDS.) WHOLE EARTH FIELD GUIDE
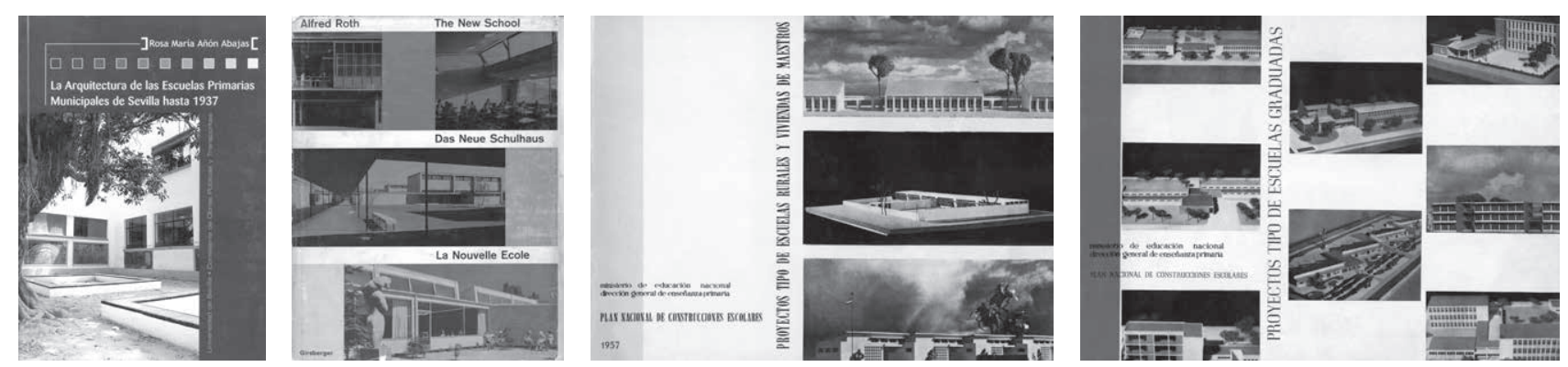

PPA N17: Rosa María Añón Abajas: LA ARQUITECTURA DE LAS ESCUELAS PRIMARIAS MUNICIPALES DE SEVILLA HASTA 1937 - Alfred Roth: THE NEW SCHOOL - PLAN NACIONAL DE CONSTRUCCIONES ESCOLARES (VOLUMEN I) PROYECTOS TIPO DE ESCUELAS RURALES Y VIVIENDAS DE MAESTROS. PLAN NACIONAL DE CONSTRUCCIONES ESCOLARES (VOLUMNE II) PROYECTOS TIPO DE ESCUELAS GRADUADAS- 

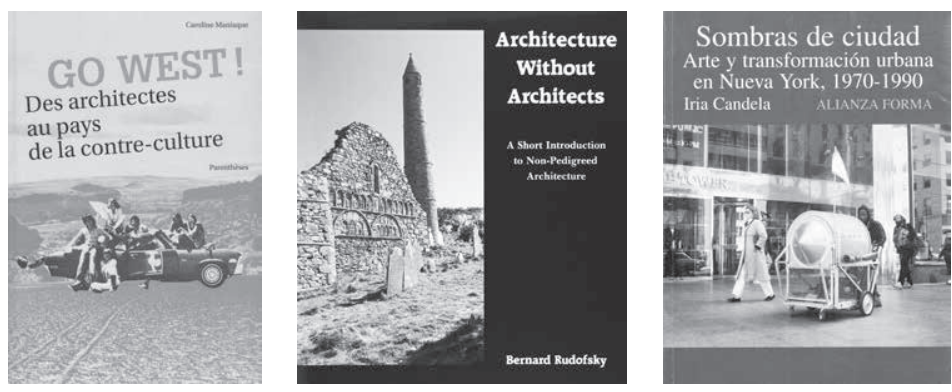

PPA N18: Caroline Maniaque: GO WEST! DES ARCHITECTES AU PAYS DE LA CONTRE-CULTURE - Bernard Rudofsky: ARCHITECTURE WITHOUT ARCHITECTS. A SHORT INTRODUCTION TO NON-PEDIGREED ARCHITECTURE - Iria Candela: SOMBRES DE CIUDAD. ARTE Y TRANSFORMACIÓN URBANA EN NUEVA YORK 1970-1990
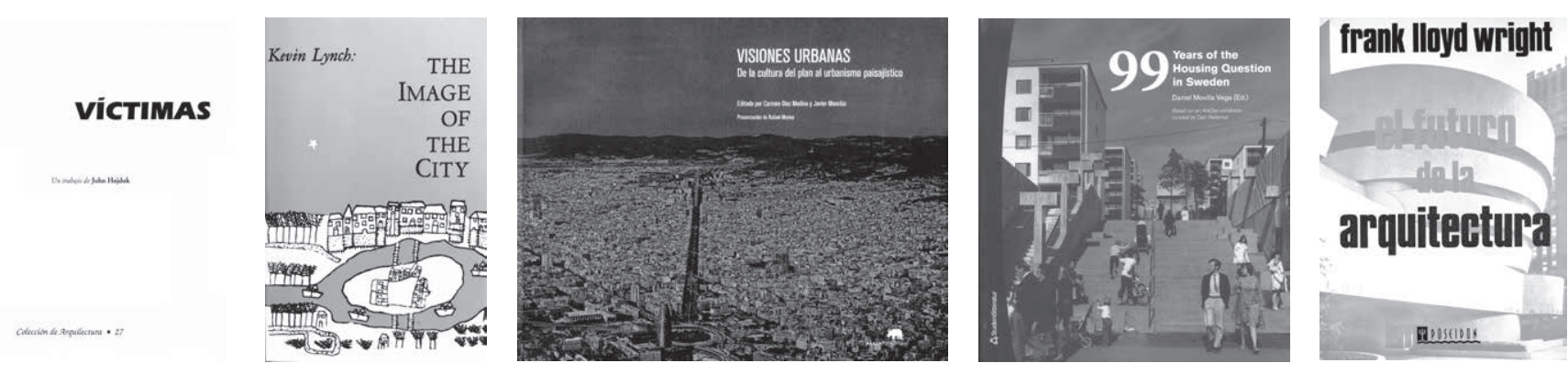

PPA N19: John Hejduk: VíCTIMAS - Kevin Lynch: THE IMAGE OF THE CITY - Carmen Díez Medina; Javier Monclús Fraga (eds): VISIONES URBANAS DE LA CULTURA DEL PLAN AL URBANISMO PAISAJÍSTICO / PPA N20: Daniel Movilla VEGA (Ed): 99 YEARS OF THE HOUSING QUESTION IN SWEDEN - Frank Lloyd Wright: EL FUTURO DE ARQUITECTURA
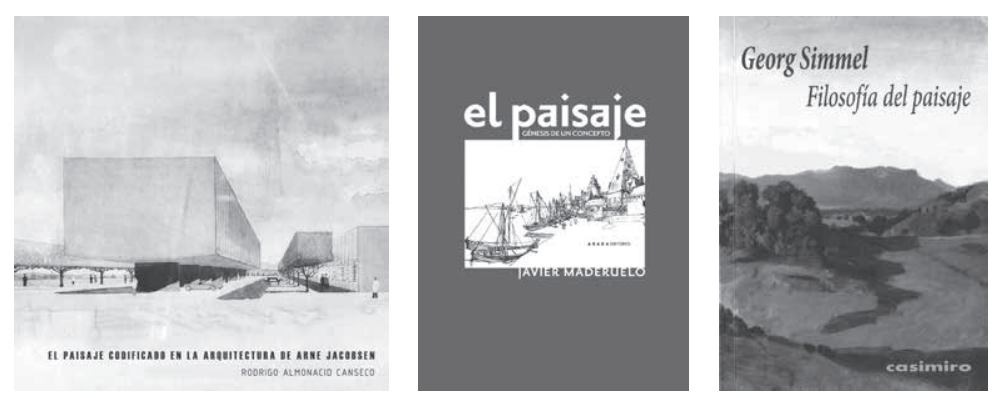

PPA N21: Rodrigo Almonacid Canseco: EL PAISAJE CODIFICADO EN LA ARQUITECTURA DE ARNE JACOBSEN - Javier Maderuelo: EL PAISAJE. GÉNESIS DE UN CONCEPTO - Georg Simmel: FILOSOFÍA DEL PAISAJE 
Y SOUTO DE MOURA / LIVING TERRACES: FROM REUSE IN TRADITIONAL ARCHITECTURE TO CÉSAR MANRIQUE AND SOUTO DE MOURA'S WORK WITH TIME. Francisco Javier Castellano Pulido • ESTRATEGIAS TERRITORIALES INTEGRALES PARA LA PUESTA EN VALOR DE PAISAJE CULTURAL AGRÍCOLA. LA RIBEIRA SACRA, GALICIA, ESPAÑA/COMPREHENSIVE TERRITORIAL STRATEGIES TO ENHANCE THE AGRICULTURAL-CULTURAL LANDSCAPE. RIBEIRA SACRA, GALICIA, SPAIN. Susana lópez Varela • PAISAJES DE ALTURA: lOS ANDENES DEL DISTRITO DE CABANA, VALLE DEL SONDONDO, PERÚ / HIGH LANDSCAPES: THE ANDENES OF THE DISTRIT OF CABANA, SONDONDO VALLEY, PERU. SOnia Delgado Berrocal • COLTIVARE I TERRAZZAMENTI AI PIEDI DEL MONTE BIANCO. LA "VITICOLTURA EROICA" DI MORGEX / CULTIVATING THE TERRACES AT THE FOOT OF MONT BLANC. THE "HEROIC VITICULTURE" OF MORGEX. Beatrice Agulli - SIAH DAREH. TERRAZAS Y PAISAJE EN ABBAS KIAROSTAMI / SIAH DAREH. TERRACES AND LANDSCAPE IN ABBAS KIAROSTAMI. Pablo López Santana • FRANK LLOYD WRIGHT. TRABAJAR LA TIERRA PARA UN PAISAJE SIMBIÓTICO / FRANK LLOYD WRIGHT. EARTHWORK FOR A SYMBIOTIC LANDSCAPE. José María Jové Sandoval • ROGELIO SALMONA Y LA CONSTRUCCIÓN DEL LÍMITE. DIÁlOgOS ENTRE TOPOGRAFÍA Y PAISAJE / ROGELIO SALMONA AND THE CONSTRUCTION OF LIMITS. DIALOGUES BETWEEN TOPOGRAPHY AND LANDSCAPE. Clara Mejía Vallejo; Ricardo Merí de la Maza • RESEÑAS BIBLIOgRÁFICAS • RODRIGO ALMONACID CANSECO: EL PAISAJE CODIFICADO EN LA ARQUITECTURA DE ARNE JACOBSEN . Carlos Santamarina-Macho • JAVIER MADERUELO: EL PAISAJE. GÉNESIS DE UN CONCEPTO. Victoriano Sainz Gutiérrez • GEORG SIMMEL: FILOSOFÍA DEL PAISA JE. Esther Mayoral Campa.

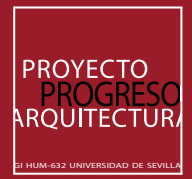
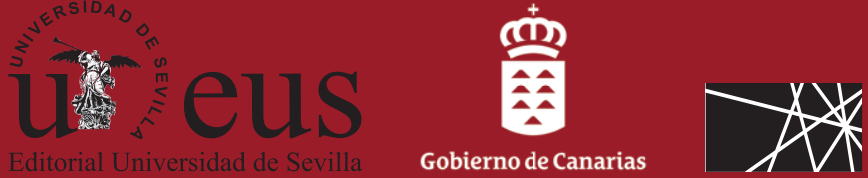